\title{
The presence of supposedly primitive human tools along the upper reaches of the Kızıl Irmak in Anatolia
}

\author{
By D. P. Erdbrink, Utrecht, and H. R. van Heekeren, Leiden
}

With 2 figures and 3 plates

$\mathrm{Z} u s$ ammenfassung. Die ersten Angaben über Flußterrassen in Ost-Anatolien wurden vor kurzem durch Izbirak (1962) und KETIN (1962) gemacht. Die Verfasser der vorliegenden Arbeit haben eine rasche und noch oberflächliche Exploration eines Terrassensystems von fünf bis sieben verschiedenen Niveaus ausgeführt entlang dem oberen Lauf des großen Kızıl Irmak (des Roten Flusses) zwischen Sivas und Kayseri in Ost-Anatolien. Teilweise ist es die von Izbirak beschriebene Gegend, größtenteils geht sie aber über diese hinaus.

Die Terrassenflächen sind ziemlich gleichmäßig entwickelt entlang des genannten Teils des Flusses, verschwinden aber plötzlich weiter unterhalb. Die Verfasser meinen mit IzBiRak, daß die Entstehung dieser Terrassen wahrscheinlich in erster Linie tektonisch und erst an zweiter Stelle klimatisch bedingt ist.

Die dritte Terrasse (von unten an gezählt) enthielt überall eine nur geringe Zahl vermutlicher primitiver Artefakten, unter ihnen einige "pebble-tools". Diese sind in vorliegendem Aufsatz beschrieben; sie stellen vielleicht einen Beweis für die Anwesenheit von frühpleistozänen Hominiden in der Türkei dar. In einem Fall wurde in dieser dritten Terrasse ein fossiler Molar eines Hipparion in situ gefunden, teilweise bedeckt mit demselben versteinerten roten Lehm, welcher auch einige der vermutlichen Artefakten einhüllte. Das Alter der Terrassen ist noch nicht genau bekannt. Es scheint aber, daß die ältesten und höchstgelegenen Tertiär sind, die Terrasse, welche die Artefakten enthält, vielleicht dem untersten Pleistozän angehört, und die untersten Terrassen in das junge Pleistozän oder gar Holozän zu stellen sind.

$\mathrm{Summary}$. The first indications of the existence of fluviatile terraces in E. Anatolia were reported recently by IzBiraK (1962) and KETIN (1962). The present authors have made a rapid and superficial exploration of a terrace system containing a maximum of five to seven different levels along the upper reaches of the great Kizıl Irmak or Red River between Sivas and Kayseri in E. Anatolia. This region partly overlaps, but lies mostly to the North of the region described by IzBirak.

It appears that the terrace levels are fairly constant along the mentioned stretch of the river. They disappear suddenly farther downstream. With IzBIRAK the present authors are of opinion that the formation of these terraces is probably due to tectonic activities in the first place and only secondarily to climatic influences. One terrace level, the third (counting from the lowest level) consistently contained a very limited number of what the authors suppose to be primitive artefacts, among which there are some pebble-tools. These are described in the paper; they may indicate the presence of hominids in Turkey during the earliest part of the Pleistocene. In one case a fossil molar of a Hipparion was found in this third level in situ, partly covered by the same petrified red loam which also enveloped some of the supposed artefacts. No exact dating of the terraces is as yet possible, but it may be inferred that the oldest and highest ones are Tertiary, the one containing the artefacts perhaps lowermost Pleistocene, and the lowest ones young Pleistocene or even Holocene.

Some time ago IzBIRaK (1962) published a geomorphological study of part of the region along the upper reaches of the Kizil Irmak in Turkey. Without being aware of the results of this study, the present authors made some observations in almost the same area. Although of a different nature these coincide very well with IzBIRAK's conclusions.

Thanks to a grant-in-aid assigned to one of us by the Wenner-Gren Foundation for Anthropological Research at New York, the voyage, and the collecting of material in Turkey, was made possible. We would like to thank the authorities of this Foundation for the rendering of this financial aid; the authorities of the Netherlands Embassy at Ankara, and Professor A. A. CENSE at Istanbul, should receive our thanks and gratitude for the aid and advice given us during our stay in Turkey.

The region visited by us was part of the upper valley of the Kizıl Irmak, the Halys river of ancient times, lying between the cities of Sivas and Kayseri. Our observations began immediately downstream from Sivas at both sides of the river over a continuous stretch of approximately 20 kilometres. Lower downstream a number of traverses at right angles to the river valley's axis was made. 


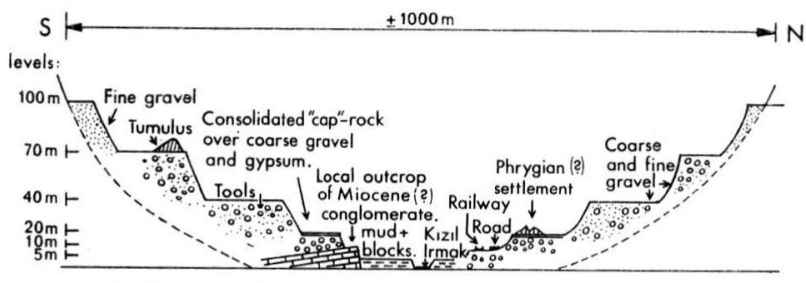

At Yapi, W. of Sivas
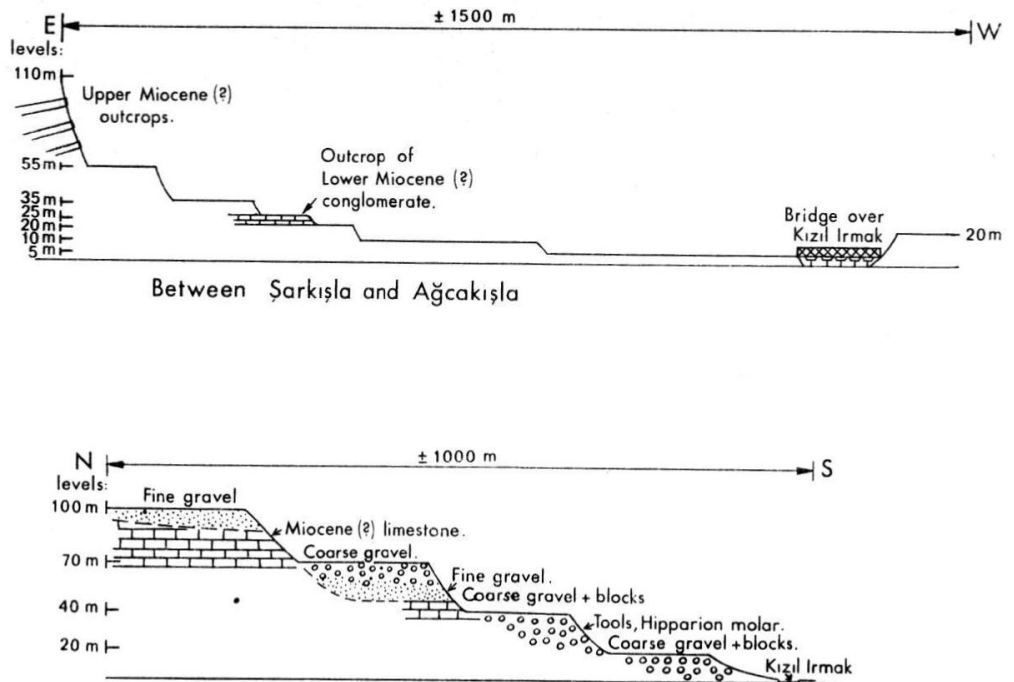

At Barsık, on the road to Felâhiye

Fig. 1. Three schematical cross-sections of the Kizil Irmak valley between Sivas and Kayseri.

A system of five to seven terrace levels, interrupted at several places, could be observed (fig. 1). Near Sivas in the neighbourhood of the large cement factory at Yapi, five terraces were present at approximately 5, 20,40, 70 and 100 metres above the level of the river during the month of September, 1963. The 5 metre level appears to be the present-day flood level of the river. Its surface consists of clay with intercalations of very coarse gravel and accumulations of limestone blocks, usually arranged as fan deposits near the outlets of small tributary valleys and arroyos. Between the edge of this level and the rise towards the next higher one, that of 20 metres, several outcrops were present of underlying rock formations. These consist of conglomerates which may perhaps belong to the Lower Miocene (Aquitanian or Burdigalian), in any case to the Miocene.

A fairly steep slope leads upwards from the 5 to the 20 metre level. At its surface this level consists of a kind of consolidated conglomeratic cap rock, in which occasional accumulations of gypsum may be found. This mineral may be derived from older Tertiary Flysch and Gypsum series, mentioned as also occurring lower downstream by IzBirak. The slope between the 5 and the 20 metre levels consists of loosely packed coarse gravel. An intermittently developed level at 10 metres may be observed. Along the East-West directed part of the valley, just to the West of Sivas and at the northern side of the river, this level has been used for the railway track and the road which connect Sivas with population centres more to the West. Its surface consists of coarse gravel and limestone blocks. Near 
Yapi, 7 kilometres from Sivas, we found several irregular mounds on top of the 20 metre terrace on the northern side of the valley. Black and red potsherds on and near these mounds might attest to their being the remnants of a small settlement perhaps dating back to Phrygian times. Near these mounds an interesting solitary flint artefact, a tanged hollow scraper (Plate $1: 1$ ) vaguely reminiscent of Aterian workmanship, made of bluish milky flint, was found by one of us. This isolated find does of course not form an argument for the contention that the 20 metre level would, at the oldest, be contemporaneous with the local Levalloiso-Mousterian.

A fairly steep slope connects the 20 and 40 metre terrace levels. The latter level consists of loosely packed coarse, and some fine, gravel. In the 40 metre terrace, i. e. on the slope

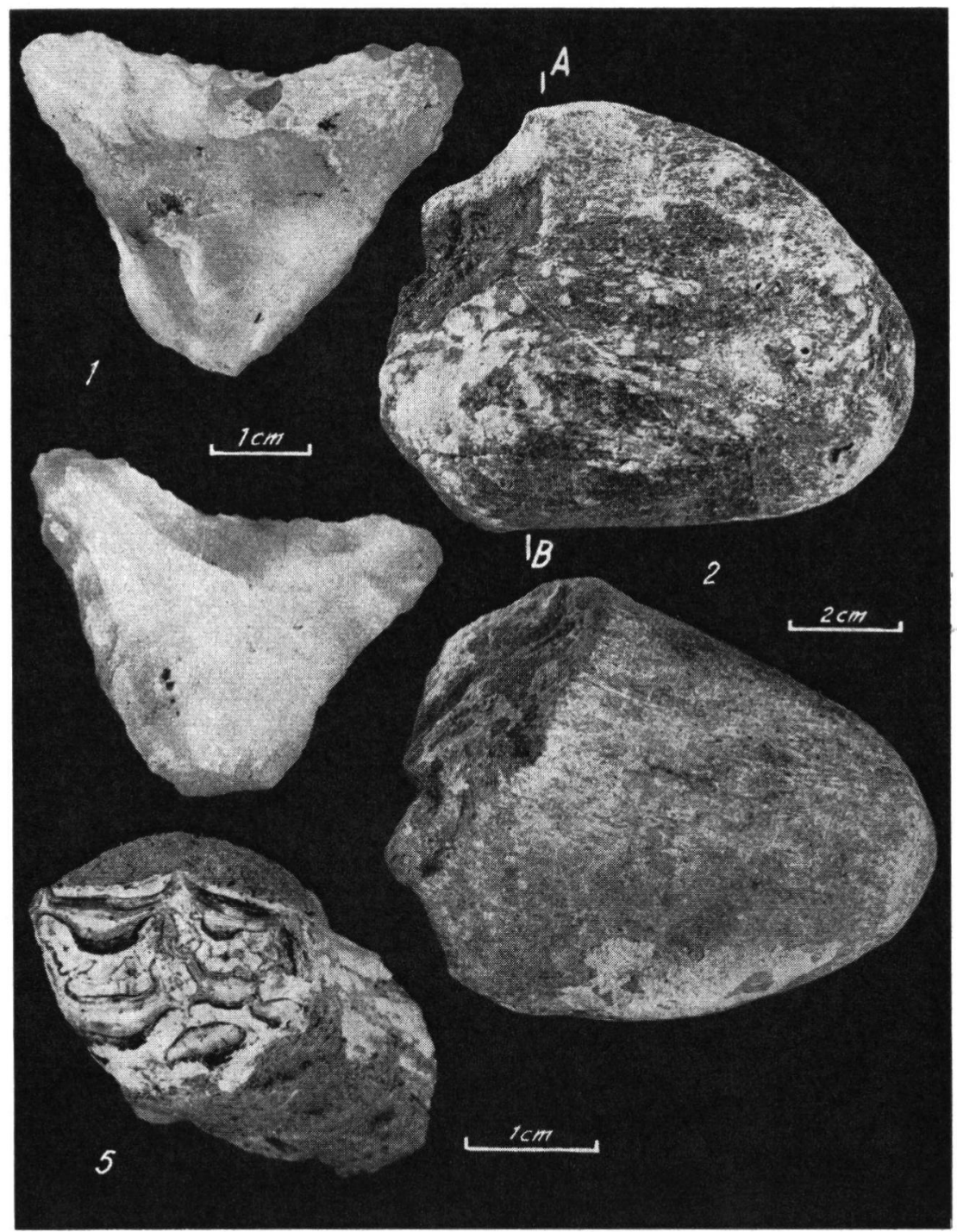

Plate 1. 1: Obverse (upper), reverse (lower) of tanged hollow scraper, $20 \mathrm{~m}$. terrace near Yapi. 2: Two aspects of Olduvan pebble-tool, $40 \mathrm{~m}$. terrace opposite Yapi. - 5;: M sup. dext. of Hipparion sp., $40 \mathrm{~m}$. terrace at Barsik; occlusal view. (Section see fig. 2.) 
between it and the 20 metre terrace, a number of primitive stone tools were collected by us. One of the most outstanding of these is a more or less typical Olduvan pebble-tool (Plate $1: 2$, and section), made of dark greenish gneiss containing serpentine. It has a greatest length of 9,5, a width of 8 and a thickness of 3,5 centimetres. The flat pebble has been worked at one end only, where two alternating flaking blows, each producing a sharp edge of $4 \mathrm{~cm}$, have given the implement a jagged cutting edge. There is a remarkable resemblance with the tool figured by LEAKey (1953) as fig. 5; but also with several of the early Soan choppers described and figured by De Terra \& PAterson (1939) from the Punjab. This tool from Turkey, perhaps the first from that country to be recognized as such, was found opposite Yapi at the southern side of the river between the 40 and 20 metre levels.

Another interesting find is a heavily rolled chopper-like object made of dark silicified limestone (Plate $2: 3$, and two sections). There is a row of five or six alternating chips along its convex curved edge, while there are two large flakes hammered off from its other, straight, edge, to provide a hold. It has a greatest length of $17,5 \mathrm{~cm}$, a width of 9 and a thickness of 4 to $4,5 \mathrm{~cm}$. It was found in situ embedded in the gravels of the $40 \mathrm{~m}$ level at a depth of approximately 6 metres in a gravel pit 3 kilometres to the West of Yapi on the northern side of the river valley. Fine gravel still adheres to the specimen and is cemented to it by carbonate of lime (as attested by its reaction with hydrochloric acid). In appearance it is definitely Preabbevillean (Prechellean), with some reminiscences of identically shaped tools from the Pleistocene of S. Java (Von Koenigswald 1936, pl. LI, figs. $6 a$ and $6 b)$.

The same may also be maintained for a small irregular hexaedric core with a flat base, made of light brown heavily silicified veinous clay or tufa (Plate $3: 4)$. One of the planes is formed by the original surface of the stone, but the other surfaces, and the base, show clear markings of rough hammering and chipping. It has a diameter of approximately $5,5 \mathrm{~cm}$, and it was found near the already described pebble-tool of gneiss. Part of a light reddish-white matrix adheres to the base. Form and size of the artefact might suggest use as a bolas-stone.

A steep incline leads up from the 40 metre level to the next one at approximately 70 metres. This 70 metre terrace consists of coarse gravel and larger blocks of stone, mostly of supposedly Upper Miocene limestones and marls (Helvetian and/or Tortonian, according to STEPCHINSKY 1939) which probably form the valley boundaries below the several alluvial deposits. On the edge of the slope towards the 40 metre level, South of the river nearly opposite Yapi, we encountered a tumulus which might date back to Hittite times, if the aspect of the numerous pottery sherds lying around it should be taken as an indication.

Finally another steep slope forms the transition between the 70 metre level and the highest terrace, which lies at approximately 100 metres above the river. This latter terrace consists solely of fine gravel.

A second perfunctory foray was made by us along a local road between Şarkışla and Agçakışla, some 60 kilometres downstream from Sivas along the Kızıl Irmak. The road crosses the river valley at right angles. Again a number of terrace levels was encountered. The first lies 5 metres above the September 1963 level of the river; it is followed up by levels at 10, 20, 25, 35, 55 and 110 metres (approximately) above the river (see fig. 1). Once more the 10 metre level is only intermittently present; so is the level at 25 metres. This latter level is formed by a bare rock ledge, probably of Lower Miocene conglomerate. Jutting out of the slope between the 55 and the 110 metre levels several nearly horizontal layers of (?) Upper Miocene limestone are visible at the eastern side of the valley (which has a direction towards the Southwest here). West of the river near a bridge in the road only the 20 and 35 metre levels are present. Higher up a rolling plain with several low 


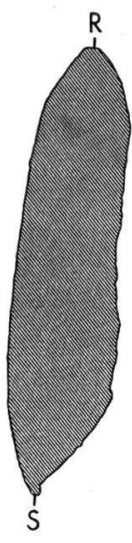

Plate 2, no 3

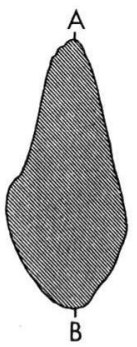

Plate 1, no2

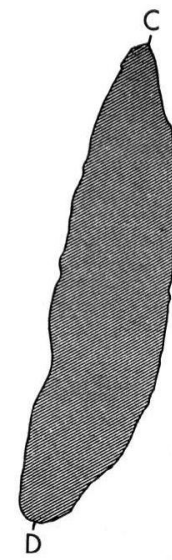

Plate 2, no 6

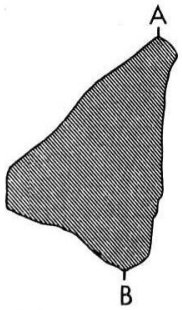

Plate 3, no7

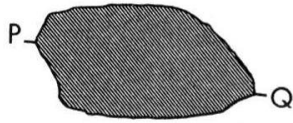

Plate 2, no 3

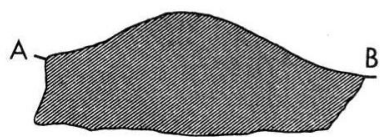

Plate 2 , no 6

Fig. 2. Sections to plates 1-3.

hills stretches out for a considerable distance. This plain contains several human settlements, and at its western boundary the slopes of the Karababa Dag and the Akdag rise to heights around 2000 metres above sea level.

The 20 metre terrace consists of rough gravel and rounded pebbles of several sizes. At a level corresponding with the 35 metre level East of the river, we collected a very dubious specimen, which might be a heavily rolled pebbletool of disclike form (dimensions: $8 \times 8 \times 2,5$ centimetres) made of silicified limestone with a blue or grey colour.

The 20 metre level did not contain as much gypsum here as it did near Yapi. Probably the $5 \mathrm{~m}$, the intermittent $10 \mathrm{~m}$ and the $20 \mathrm{~m}$ levels are identical at both visited localities. The $40 \mathrm{~m}$ level near Sivas and the $35 \mathrm{~m}$ level here, and the $100 \mathrm{~m}$ level near Sivas and the $110 \mathrm{~m}$ level here may probably be correlated also. No traces of a $70 \mathrm{~m}$ level could be found here.

A third locality where we made a partial cross-section was further downstream again, along the secondary road to Felâhiye, which branches off from the main road between Sivas and Kayseri. Here the Kizil Irmak follows a tortuous course through a narrow defile, while a number of tributary rivulets have carved out small valleys which stand more or less at right angles to the main ravine of the Red River. One of these is a small valley at a locality called Barsık, along which the road towards Felâhiye winds upwards after the crossing of the Kizil Irmak.

The nearly dry bed of the rivulet at Barsik offers a good natural section (fig. 1) of a set of river terraces. These run approximately parallel to the Kizil Irmak from East to 


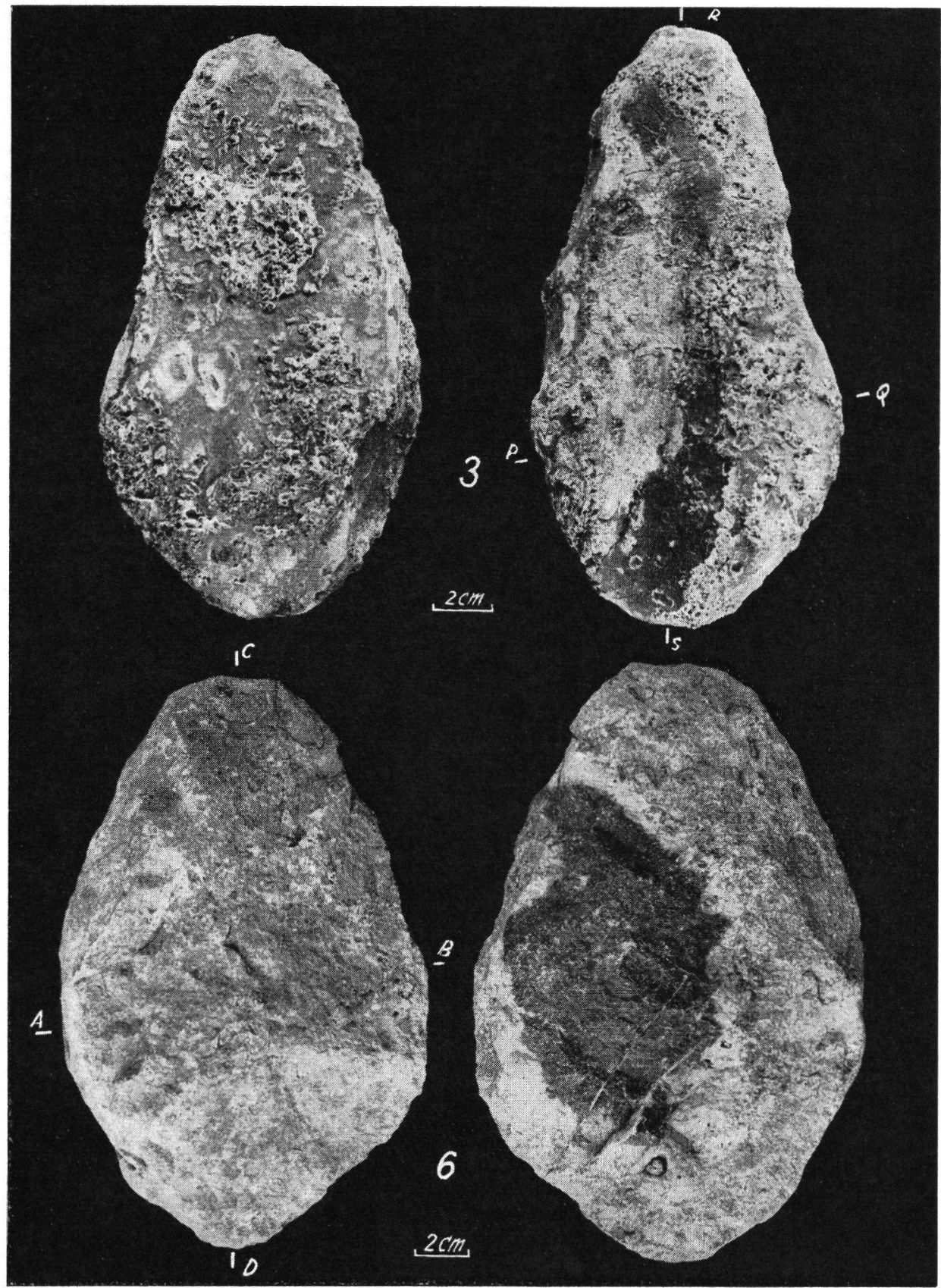

Plate 2. 3: Obverse (right), reverse (left) of rolled chopper with adhering gravel, found embedded in $40 \mathrm{~m}$. terrace near Yapi. - 6: Obverse (left), reverse (right) of large oval chopper with remains of fossil molluscs in it. $40 \mathrm{~m}$. terrace, Barsik. (Sections see fig. 2.) 
West, and the Barsik rivulet runs from North to South. Terrace levels could be distinguished at around 20, 40,70 and 100 metres above the September level of the Kizil Irmak. Probably these are the same levels as those seen by us near Sivas and between Sarkisla and Agçakışla. The 20 metre terrace consists of rough gravel and rolled pebbles, partially derived material from the (underlying?) Miocene limestone in the neighbourhood. The 40 metre terrace has nearly the same constituting material, while the 70 metre terrace contains rough gravel and pebbles of Miocene limestone in its upper half but only fine gravel near to the bottom. The 100 metre terrace consists of fine gravel only; the Miocene (?) limestone immediately below it has partly been cut through by the Barsik rivulet also. Between the 20 and 40 metre levels we were able to collect some implements, and also a first or second permanent molar (Plate 1:5) of the right upper jaw of a Hipparion sp. (a rather small type), which was found in situ among the cemented gravels of the $(40 \mathrm{~m})$ terrace. Part of this molar was covered with a red fossilized loam, containing a large amount of lime (as attested by the reaction with hydrochloric acid). Among the artefacts a large, flat, oval chopper $(20 \times 12,8 \mathrm{~cm}$, with a thickness of $4,7 \mathrm{~cm})$ of grey silicified limestone with vestigial remains of fossil lamellibranchs and gastropods in it (Plate $2: 6$, and two sections), should be mentioned. Its underside is nearly flat, while the upper side has eight different flakes chipped off in such a way that about half of the length of its long edge has been made into its working or chopping part. There is rough secondary flaking along the same edge on the underside. The part of the artefact which is to be held in the hand is fashioned by several abrupt retouches. A section along its short axis shows an abrupt slope to one edge and a gentle slope to its other, or chopping, edge. This tool resembles choppers known from S. E. Asia.

Another artefact, also a kind of chopper (Plate $3: 7$, and section), is made of the same material. It is nearly semicircular in outline $(11 \times 7 \mathrm{~cm}$, with a thickness of $4,5 \mathrm{~cm})$, having a flat underside and a kind of keel running over its entire length parallel to the abrupt and straight edge. The chopping edge is made up of three or four facettes. One of these, at one of the short ends of the tool, makes the impression of having been reworked by secondary flaking into a scraper-like plane, thus giving the artefact the aspect of an endscraper (Movius 1950, p. 116).

This tool, and the first one, show some of the same red fossilized loam, present in interstitial cavities, which was mentioned in the description of the Hipparion molar. The loam also adheres to a third implement (Plate $3: 8$, and section), a disclike tool of white or bluish flint with a diameter of approximately $7,5 \mathrm{~cm}$ and a maximum height (near its centre) of $4 \mathrm{~cm}$. Its underside is practically flat, and its upper side has a sharp cutting edge, produced by four to five rough attempts at flaking, along nearly half of its circumference. The rest of the stone has been left in its original rounded and pebble-like state, no doubt in order to afford a good hold. In shape it somewhat resembles a larger and rougher edition of von Koenigswald's round scraper (1936, p. 56, pl. LVI, fig. 4) from Patjitan, Java.

A final observation of possible terrace levels along the $\mathrm{K}_{1 \mathrm{z}} \mathrm{l}$ Irmak was made by us along the main road from Kayseri to Kurşehir, where it crosses the river over an ancient Seljuk bridge some distance from the village of Himmetdede. To the North of the river four to five levels may be observed: at 100, 70, 40, 20 and perhaps at 10 metres above the September 1963 level of the river itself. An andesitic lava flow appears to have covered each of these levels with the exception of the lowest one at 10 metres. The flow has a thickness of one to two metres. Immediately below it there is a volcanic tufa of $1 / 2$ to 1 metre thick, which covers the terrace deposits proper. No artefacts were found by us here, but it is again remarkable that the several recognizable levels are present at approximately the same heights above the river as at the other three described localities. If a more thorough exploration might show that the volcanic deposits are the result of a single 


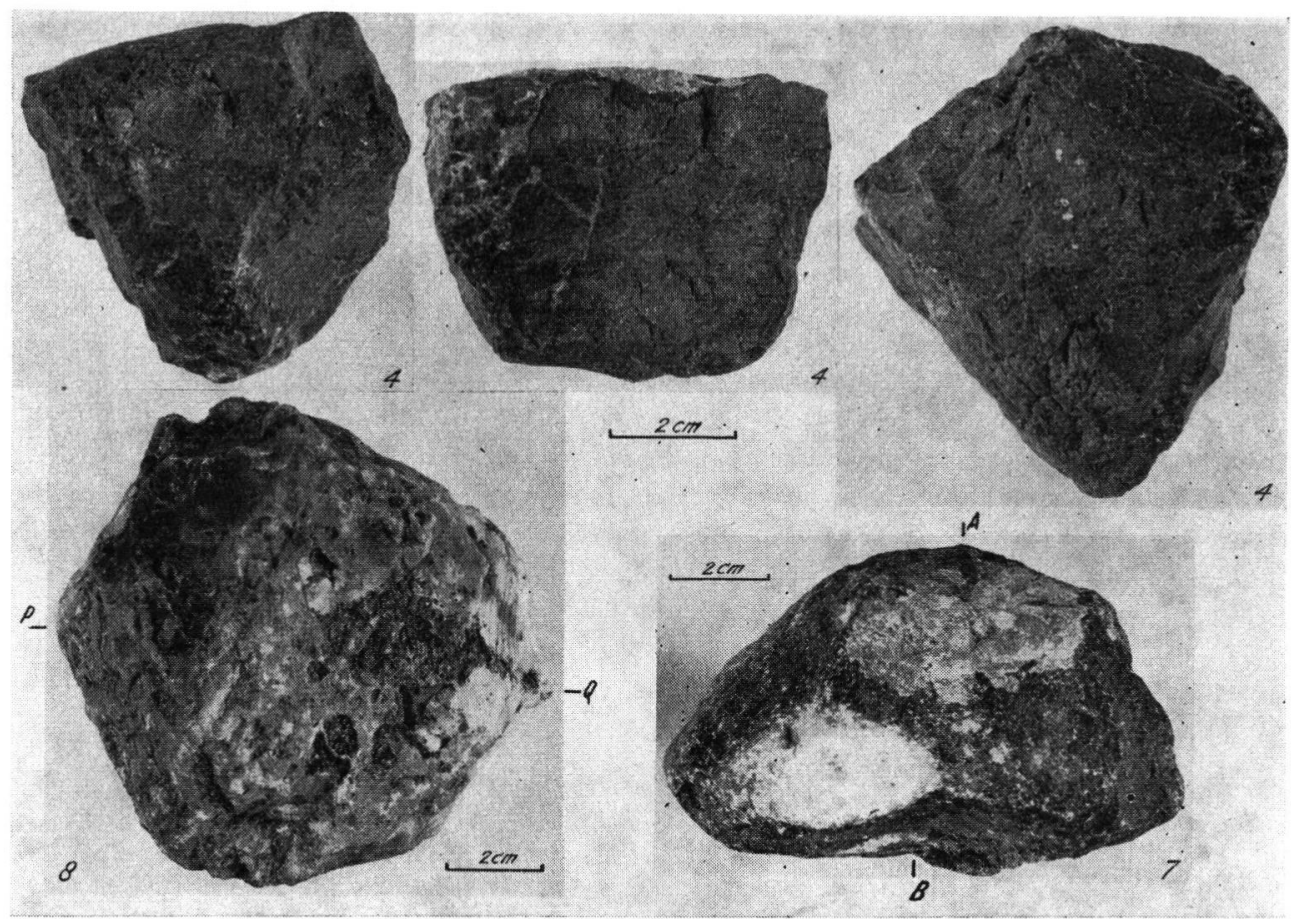

Plate 3. 4: Three aspects of irregular hexaedric core with flat base (or top) of light brown silicified tufa. $40 \mathrm{~m}$. terrace opposite Yapi. - 7: Upper view of semicircular chopper / endscraper. $40 \mathrm{~m}$. terrace, Barsik. - 8: Upper view of disclike round scraper of whitish flint. $40 \mathrm{~m}$. terrace, Barsik. (Sections see fig. 2.)

outburst, this might furnish an approximate date post quem for the age of the lowest level of 10 metres and a date ante quem for the 20 metre level.

The rolled appearance of many of the supposed artefacts may indicate either that they are derived from a higher level than what we would like to term here the 40 metre terrace, or that the time during which this 40 metre terrace was formed, has had a considerable length. The latter possibility appears to us to be most likely, because we have not been able to find any tools or fossils in a higher level than that of the 40 metre terrace. A slight indication for the considerable antiquity of the 40 metre terrace is provided by the Hipparion-molar at Barsik; this sustains the impression made by the primitiveness of the supposed artefacts. However, this single fossil may have rolled down from another and older deposit as well, although it may be significant that the fossil red loam with which it is covered is absolutely the identical matrix enveloping some of the tools.

Allusion has already been made to the resemblance of the few collected artefacts with both the primitve African, and the primitive Asiatic tool types, such as the Olduvan, Soan or Patjitanian ones. One has only to consult the descriptions and figures in partly already mentioned publications by De Terra \& Paterson, von Koenigswald, Leakey, MortelMaNs (1952) or Movius $(1948,1950)$, to see the conformity. It should be remembered that this remark is also true for two other assembly-areas of primitive artefacts in not too distant regions: the tools described by VAN LIERE (1961) from Syria, and those by Stekelis, Picard, Schulman \& HaAs (1960) from the central Jordan valley near Ubeidiya, a Villafranchian deposit. The geographical situation of the entire region almost implies that a mixture of Asiatic and African influences has to be expected, as in the case 
of faunal assemblies such as the one described by HoojJer (1959) from Jisr Banat Yaqub near lake Huleh in Israel.

While fragmentary remains of the tool maker himself have been found at Ubeidiya, this is not yet the case along the upper reaches of the Kizil Irmak. We may perhaps expect some pithecanthropine from of Homo, or even something like the recently described Homo babilis Leakey, Napier et Tobias (1964).

To summarize the picture up to this point, we are inclined to believe that the described flaked pebbles are genuine tools. This may be correct, but it cannot be denied that personal judgement plays a large part in the question. It should be realized that it is not easy to distinguish between the simple fabricated pebble-tools and naturally fractured pebbles. Unfortunately for our purpose the records at our disposal are scanty. Much more evidence is required for a confirmation; a much greater wealth of pebble-tools, more detailed stratigraphic and palaeontological evidence, are urgently needed. The present notes should be seen as still more or less belonging in the realm of hypothesis with a provisional nature, to be tested by future research.

The typical terrace formations mentioned by us are entirely absent more downstream along the Kizil Irmak. Lower down along this river, however, terrace formations seem to be present again. KETIN (1962) mentions the existence of unspecified terraces along the Budaközü stream, a tributary of the Kizil Irmak, near Sungurlu, as well as in the area South of Osmancik and near Karg1 and Bafra along the Red River itself. According to him they lie 5 to 8 metres higher than the present flood plain of this river and consist of gravel and cross-bedded sands. He also cites YALCINLAR (1958) for the observation of the presence of terraces near Bafra. South of Osmancik there are remnants of old terraces at a level of 7 to 8 metres above the present valley. The geological description of the area shows that the river follows a course through a number of tectonically influenced basins. This explains why terraces may be present in one and absent in another area along the river, while the levels at which they may be found need not be identical in different basins. We tend to agree absolutely with IzBirak's conclusions that the terraces along the Kizil Irmak and its tributaries along the stretch between Sivas and Kayseri are to be seen as the results of a combined erosion of the river through soft Tertiary deposits, and an uplift of comparatively large mountain areas such as that of the Akdag. This tectonical activity may safely be dated as beginning in Upper Pliocene times (IzBIRAK 1962, p. 40) and going on during the Pleistocene very probably until modern times. Tectonical movements of an entirely different nature and age are probably responsible for the absence of terraces along the Kizil Irmak at other places. Changes of sea level very probably have played no role of importance at all in the formation of the terraces along the Kizll Irmak in its upper reaches. Tectonic movements, perhaps combined with climatic changes, should be seen as the sole agents.

\section{Bibliography}

De Terra, H. \& Paterson, T. T.: Studies on the Ice Age in India and Associated Human Cultures. - Carnegie Institute of Washington, Publication 493, 354 pp., 1939.

Hoorjer, D. A.: Fossil Mammals from Jisr Banat Yaqub, South of lake Huleh, Israël. - Bulletin of the Research Council of Israel, T. 8 G, no. 4, 195,9.

IzBIRAK, R.: Geomorphologische Beobachtungen im Oberen Kizilirmak- und Zamanti-Gebiet (östliches Mittelanatolien). - Münchner Geographische Hefte 22, 53 pp., 1962.

Ketin, I. (compiler): Türkiye Jeoloji Haritası (Explanatory text of the geological map of Turkey), $1: 500000$, Sinop. - 111 pp., Ankara, M.T.A. Enstitüsü, 1962.

Koenigswald, G. H. R. von: Early Palaeolithic Stone Implements from Java. - Bulletin of the Raffles Museum, Singapore, Series B no. 1, pp. 52-60, 1936.

LEAKEY, L. S. B.: Adam's Ancestors. - 4th Ed., London 1953. 
Leakey, L. S. B., Napier, J. \& Tobias, P. V.: A new species of the genus Homo from Olduvai Gorge. - Nature 202, no. 4927, pp. 7-9, 1964.

LIERE, W. J. vaN: Observations on the Quaternary of Syria. - Berichten van de rijksdienst voor het oudheidkundig bodemonderzoek 10-11, pp. 7-69, The Hague 1960/61.

Mortelmans, G.: Contribution à l'étude des Cultures Pré-Abbevilliennes à galets taillés du Katanga: Le Site Mlundwa 1. - Brochures publ. par la Société Royale Belge d'Anthropologie et de Préhistoire en l'honneur du Professeur Hamal-Nandrin, 1952.

Movius, Jr., H. L.: The Lower Palaeolithic Cultures of Southern and Eastern Asia. - Transactions American Philos. Society 38, pp. 329-420, Philadelphia 1948. - - Zur Archäologie des Unteren Paläolithikums in Südasien und im Fernen Osten. - Mitteilungen der Anthropologischen Gesellschaft in Wien 80, pp. 101-139, 1950.

StePChinsky, V.: Faune miocène du vilâyet de Sivas. - M.T.A. Enstitüsü, Ankara, Monographie no. $1,1939$.

Stekelis, M., Picard, L., Schulman, N. \& Haas, G.: Villafranchian deposits near Ubeidiya in the central Jordan valley (Preliminary report). - Bulletin of the Research Council of Israel, T. $9 \mathrm{G}$, no. 4, 1960.

YaLCinlaR, I.: Samsun bölgesinin Neojen ve Kuaterner kıyı depoları. - Istanbul Ưniv. Cog. Enst. Dergisi, C 5, S. 9, 1958.

Manuskr. eingeg. 20. 4. 1965.

Anschrift der Verf.: Dr. D. P. Erdbrink, Utrecht, Janskerkhof 3; Dr. H. R. van Heekeren, Leiden, Steenstraat $1 \mathrm{~A}$. 